\title{
PIONEER
}

VOLUME 11, Issue 2, December 2019: 77 - 89

\section{PSYCHOANALYSIS OF MAIN CHARACTER'S PERSONALITY IN THE MOVIE MOANA}

\author{
Izzah Afkarina \\ University of Abdurachman Saleh Situbondo \\ afkarina527@gmail.com \\ Dwi Taurina Mila \\ University of Abdurachman Saleh Situbondo \\ dwi.meela@gmail.com
}

\begin{abstract}
Psychoanalysis is the study of human nature and personality. The purpose of this research is to find the personality of main character and the factor of personality development in the Movie Moana. This research used descriptive qualitative method by Creswell. The analysis was started by explaining the id, ego and super-ego by Sigmund Freud in Calvin S. Hall (1954), identifying with the factor of personality development by Kuravati and Malipatil (2017) and making conclusion. The results of the analysis showed that there are eleven data in this thesis which include the structural personality (id, ego and super-ego). The researcher found some factors that indicated to development of Moana's personality that are heredity from individual factor and physical environment, family environment, cultural environment and social role from environment. Moana can cross the ocean because she wanted to save people of Motunui from economic down turn. This movie has some messages about the desire of child. Therefore, the researcher suggested the next researcher to do further research. This research also expected to enrich the knowledge of the reader about psychoanalysis.
\end{abstract}

Keywords: ego, id, factor influence personality development, Moana, psychoanalysis, superego

\section{INTRODUCTION}

Psychoanalysis is the study of human nature and personality. This theory is developed by Sigmund Freud in Calvin S. Hall (1954). Every human has personality itself. It is not only have one trait, but diverse of personality. Human have three mental system that are id (pleasure), ego (act, behaviour) and super-ego (moral, ethical, values, parental). It can be assumed that the nature and behaviour of people is carried out on the basis of motives without being aware or on the basis of thoughts, feelings, tend to do without conscious and partly being conscious. The essential of studying psychoanalytic science is that we can find out how human character or ourselves when doing things unconsciously or how human behaviour when having problems. Every human being has 
a different problem.

This phenomenon happen to humans make an author has an idea to create a literary works, such as short story, drama, novel or movie. Literary works as psychological phenomenon is a condition role psychiatric illustration. Jatman in Gisela (1985:57) explains that literary works and psychology have a close relationship, indirectly and functional. The word "indirectly" is literary works with psychology has the same one thing that is human life. While "functional" is in the study of psychiatric. The relationship of literary works and psychology also has different thing that is about treatment. If psychology is something done real and can be seen in terms of behaviour, while literary works is something done through an imagination.

One of literary works that tells the psychological aspect is Movie Moana. Moana is one of Walt Disney movie which so popular in 2016-2017. This movie is about the desire of child whose name is Moana. She want to cross the ocean to save people of Motunui from economic downturn, but she always banned by her father. Moana's personality is selected as the research object.

The researcher was conducted this research based on some research problems and objectives. The research problems are how are the id, ego and super-ego of main character in the Movie Moana? And what factors affect id, ego and super-ego of main character in the Movie Moana? Moreover, the objective of this study was to explain the id, ego and super-ego of main character in the Movie Moana. Another exploration was to describe the affect id, ego and super-ego of main character in the Movie Moana.

The researcher regarded the research issues raised to limited variables. The researcher restricted to psychoanalysis of Moana and the factor affected the psychoanalytic of Moana.

\section{REVIEW OF LITERATURE}

\section{Psychoanalysis}

Barry in Rahayu (1995: 96) stated that psychoanalysis itself form of therapy which aims to cure mental disorders. Psychoanalysis was developed by Sigmund Freud as a psychiatrist. Freud adduce that psychic life contains two parts that are conscious and unconscious. This is explained part of unconsciousness likened to the part of the iceberg which is named on the sea surface. Part unconsciousness, which is much larger, 
is below sea level, contains instincts that encourage all human behaviour.Afterwards, Freud developed his theory into a structural manner. According to Freud, the structural personality are $i d$, ego and super-ego.

\section{Id}

Id is a one of formation of human personality to give a pleasure in humans. In short, id only thought about enjoyment and pleasure. Basically, id has appeared since people were born. Besides, id also called as Primary Process or can be interpreted as the working of unconscious process. Freud in Calvin (1954:22) the aim of pleasure principles is to rid the person of tension. This response can be assumes that every people want happiness. It means every people often doing things that make them happy only to satisfy themselves. It stated that Id tent to appear in humans to look for a pleasure.

\section{Ego}

Ego is personality system that act as individual director to reality object and carry out the functions based on reality. Ego as the executive apparatus of personality, regulates and controls the Id and Super-ego also builds relationships with the outside world for the sake of the overall personality along with its long-term needs. Freud in Lapsey (2012) First, ego begins to describe not only as an impersonal "apparatus" whose function is to de-tension the biological strivings of the organism or as a "device" for mastering excitations, but rather as a personal self. Second, development is Freud's tentative hypothesis that ego development entails the renunciation of narcissistic selflove in favour of the idealization or aggrandizement of cultural and ethical ideals, which is represented to the child by the influence of parents.

\section{Super-ego}

Super-ego is about value, rules, ethical and moral of personality system. It is also involved good or bad things of what people want or what people do. The super-ego works is reverse from id's works. Super-ego is moral aspects of personality because it is specify about what something true or false, appropriate or not, so as someone can act something with moral of society. According to Freud in Calvin (1954: 81) fear of punishment and desire to approval make children identify themselves with parents moral advises. Identify of parents obtain to super-ego formation. 


\section{Factors that Influence Personality Development}

Kuravati and Malipatil (2017: 608) stated that there are two parts of factors affecting personality development, such as:

\section{Individual Factors}

\section{Heredity}

Heredity is something that pass from generation to generation. It is due to the genetic transfer from parents to children, that is the skills and traits that pass from parent to children. The traits or skills who parents have can affect a personality of children. Heredity factors may be summed as constitutional and biological factors:

Constitutional factors

This factor is determining the type of people's personality. There are three bodily types of personality (1) short and stout (2) tall and thin (3) muscular and well proportioned. Body shape of someone can affect their personality. If their body not nice looking, it can be victims of bullying. Whereas, having a perfect body can make them feel confident.

\section{Biological factors}

The working of the nervous system, glands, blood chemistry determines our characteristics and habitual modes of behaviour. These factors form the biological basis of our personality. Adler points out that personality defects lead to the development of inferiority complex and the mental mechanism of compensation. Biological factors also include the mental ability of the child. The role of parents is very important in this factor. Biological factors related to the mentality of a child, how to build their mental well. If the parent is not good enough or does not understand how to shape the child's mentality, they can have a low mentality.

\section{Intelligence}

In general, people who are intelligent, so easy to adapt to the social environment, either at home or at school than those who are less intelligent. Someone who has intelligence is more adaptable to the environment and people around them. Intelligence can affect personality because they can adapt (adjustment) wherever they are.

\section{Sex Differences}

Sex differences play a vital role in the development of personality of individual. Boys are generally more assertive and vigorous. They prefer to adventures. Girls are 
quieter and more injured by personal, emotional and social problems. From this factor it can be said that boys use reason and body language more and girls use their feelings and emotions to develop their personality.

\section{Nervous System}

The nature of nervous system can influence the personality development. Psychologists believe that a person with more complex and developed nervous system has greater level of intellectual capabilities. It is considered more able to adjust with different situations. Development of nervous system determines a person's actual accomplishment in the society and his social status in the society.

\section{Environmental Factors}

\section{Physical environment}

The physical includes the influence of climatic of a particular area or country. Example, the dark weather and thick clouds can make children afraid and do not want to go out. The condition of physical environment can affect the personality development of child.

\section{Social environment}

The social environment is important thing to the personality development of child. When the social environment around children is good, their personality will also develop well. Whereas, the social environment is bad, having neighbours like to drunk or a robber, etc, course the child will have a personality like them.

\section{Family environment}

Behaviour, attitude, education and attention from parents are very important for children. If children less attention, less education or anything from their parents, they cannot control their emotional or children will feel lacking affection. Then, it will affect their personality development.

\section{Cultural environment}

The cultural environment refers to certain cultural traditions, ideals, and values etc., which are accepted in a particular society. All these factors leave a permanent impression on the child's personality. Tradition and culture values in society can influence the personality development. 


\section{School environment}

Atmosphere and discipline regulated by school can influence to the personality development. Teacher's character, peer student attitude and character. The school poses new problems to be solved, new taboos to be accepted into the superego and new models for imitation and identification, all of which contribute their share in molding personality.

Other factors which influences the development of personality:

\section{Language}

Language is an important vehicle by which the society is structured and culture of the race transmitted from generation to generation. The child's personality is shaped by the process of interaction through language with other members of his environment. Language also influenced human personality from how they talked, is it good talk or bad talk, polite talk or impolite.

\section{Social role}

The child has to play several roles like son, brother, student, officer, husband, father, etc., throughout their life at rent stages of their development. Social roles may be described as process by which the co-operative behavior and communications among the society members are facilitated. They will know how are live outside their selves.

\section{Self-concept}

self-concept influences our personality development in two ways (1) if other people hold high positive ergative enhances ourselves (2) if others hold may us, it creates of worthlessness and to self-defense or with draw from social situation.

\section{Identification}

it is an important mechanism by which we try to imitate the physical, social and mental characteristics of our model. It is very important relationship with others.

\section{Inter personal relations}

It is among the member of a society are important means which help in the development of certain social personality characteristics, like attraction towards others, concept of friendship, love, sympathy, hostility and also isolation which is a negative orientation.

\section{Psychological factors}

These include our motives, acquired interests, our attitude, our will and 
characters, our intellectual capacities such as intelligence.

\section{Movie Moana}

Moana is one of Walt Disney movie which is popular in 2016-2017. The movie tells about a princess whose name is Moana. Her imagination began to emerge when the grandmother told of the life of an island that lived happily with its marine income, but a bad incident hit the island. The attraction of Moana on the sea make Moana's father worried. Every time Moana approached the sea, she always got angry by her father. Moana's grandmother hopes that Moana can return Te-Fiti's heart in order to save the economy of Motunui people which began to decline. Moana realized that it was too dangerous for her to sail the sea, she was reluctant to continue. Her heart and mind began to shake when she saw her grandmother sick. Finally, her mother supported the wishes of Moana. In the middle of the trip, Moana felt a failure and wanted to go back, as soon as her enthusiasm returned and pushed her mind to continue to move on.

\section{METHOD}

This research used descriptive qualitative research method from Creswell by using library research and browsing. The researcher used the library research in gathering the data. The data source, the researcher chose Movie Moana. In this movie, the main character's personality is more prominent in the explanation of psychological structure. The research data are action, dialogues (utterance) and situation which show the psychoanalytic personality of main character in the movie Moana.

The data collection technique used were; first, watching the movie to get understand, to check and collect the data of psychoanalytic personality of the main character. Second, Screenshoting the scenes of story refer to the data. Third, Selecting the scenes (utterances, acting and situations) that indicate psychoanalytic structure of main character. The last, noting down the data in the table of data collection.

To analyse, it used three steps from experts, these are explaining the data based on the psychoanalytic structure in the movie Moana by using theory from Freud in Calvin (1954). Psychoanalytic structure that are id, ego, super-ego. Identifying the factors of personality development on Moana, the researcher used the theory from Kuravati and Maripatil (2017), then making conclusions. 


\section{FINDINGS AND DISCUSSION}

\section{Individual Factor}

Heredity

Code 001/MM/00:04:57- 00:05:17

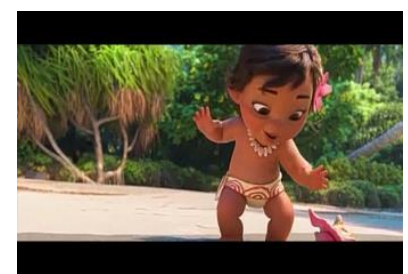

Figure 1. Moana want to took the beautiful trumpet shells (id)

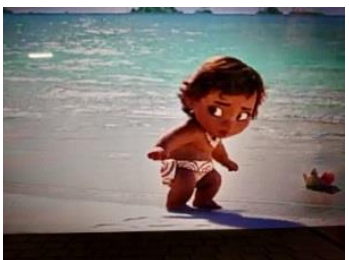

Figure 2. There was a Turtle's child want to go out, but blocked by birds (super-ego)

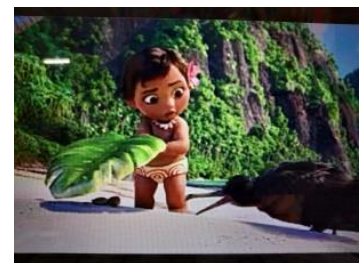

Figure 3. Moana chose to help the turtle's child from birds (ego)

This data showed that Moana want to take a beautiful trumpet shells in the edge of sea. Here, the id appeared. The super-ego in Moana hold to take the trumpet shells, because there was a turtle's child hiding in a whole. The turtle's child want to go out, but it blocked by birds, so it cannot pass. Moana was confused, which will she chose, followed the id or the super-ego. Finally, Moana chose to help the turtle's child to out from hiding covered up leaf. This action of Moana called ego. In this scenes, the factor of personality development of Moana is heredity. It happened because Moana's family liked to help people who need help.

\section{Environmental Factors}

\section{Physical environment}

\section{Code 010/MM/01:15:24-01:15:36}

Maui : "What are you doing?"

Moana : "Finding you a better way in!"

Maui : "We won't make it!" 


$$
\begin{array}{ll}
\text { Moana } & \text { :"Yes, we will!" } \\
\text { Maui } & \text { :"Turn around!" } \\
\text { Moana } & \text { : "No!"” }
\end{array}
$$

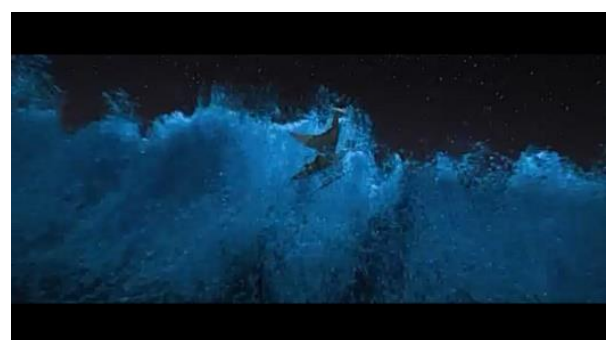

Figure 4. The big wave hit Moana's boat and Maui

In this scene, Maui (a demigod) was fighting with Te-Ka (an evil who kept TeFiti) in the middle of the ocean. From the dialogues, id of Moana wanted to help Maui to get a better way to pass from Te-Ka, but Maui banned her to continue her planning, because it would not success (super-ego). Maui had knowned that Moana's planned impossible to success passed from Te-Ka. Moana did not listen what Maui spoke, she still continued her plan to get a better way for Maui (ego). Finally, a big wave hit Moana's boat and Maui. The physical in the sea was dark and a big obstacle from TeKa made Moana and Maui failed to pass from Te-Ka. It include to the factor of personality development.

\section{Cultural environment}

\section{Code 002/MM/00:07:21-00:07:31}

Moana : "What? I wanna's go back"

Father : "I know, I know, but you don't go out there. It's dangerous."

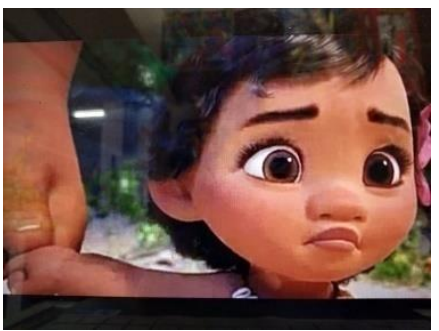

Figure 5. Moana seem sad and dissapointed because she want to back to the sea. (id)

In this, the id of Moana appeared when she wanted to back played water in the sea, but her father banned Moana to come back to the sea. The researcher assumed that her father ban said as a super-ego for Moana. The id of Moana did not fulfilled, therefore Moana felt sad and disappointed (it is called ego). If id cannot follow the desire, people can do anything beyond the control of ego. This factor is about culture 
because in this movie the father will tell there is a rule for people in this island about going to the sea. The rules prohibited citizens of island to going to the sea.

\section{Social Role}

\section{Code 009/MM/00:30:16-00:31:48}

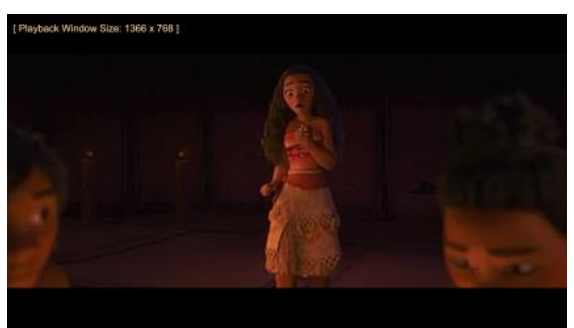

Figure 6. Moana want to accompanied her grandma who is getting sick (id)

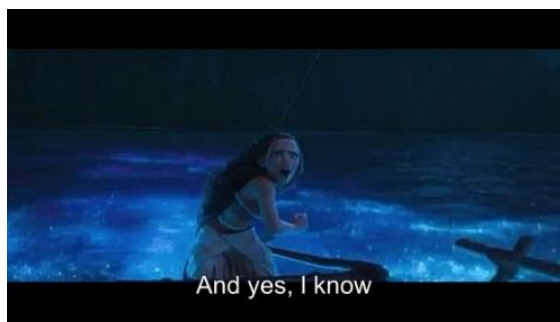

Figure 7. Moana crossed the sea for her grandma and for her people (ego)

In this scene, Moana's grandmother fell sick. Moana felt pity when she saw her grandmother helpless. There are few dialogues between Moana with the grandmother.

Grandmother : "Go!"

Moana : "I can't leave you"

Grandmother : "There is nowhere you could go that I won't be with you."

In the form of dialogues, the super-ego from her grandmother gave support to Moana to cross the sea for the sake of returned the heart of Te-Fiti. Id of Moana just wanted to accompany her grandmother, she did not wanted leave her grandma. Then, ego can controlled the super-ego and id, she cross the line for her grandma and her people to save them from economic down turn by returned the heart of Te-Fiti. The factor of personality development in this scene is social role. As the heir of her father's throne, she felt that she must do what her grandmother asked her, to save the Motunui Island and the people on it. 


\section{Discussion}

The result from the analysis showed that there were eleven data from the dialogues, action and situation in the Movie Moana. The ego dominantly managed to control the id and several times ego cannot follow the desire of id. The consequence of the desire of id cannot be followed by ego. It could feel angry, cry, dissapointed, etc. There are several ego cannot follow id of Moana, the consequence she was always angry and annoyed.

Furthermore, the researcher found some factors that indicated to development personality of Moana. The first factor was from individual factor, heredity. This factor made Moana become a kind child because her parents were so kind to people. So that, she has helped a turtle's child to go out from their hiding that blocked by bird.

The second factor was from environment. There were two data of physical environment, one datum of family environment, five data of cultural environment and two data of social role. The most frequently appeared factors of personality development in Moana was cultural. The cultural is about the rule of the island. It means the culture in that island strongly affected personality of Moana. The rule was prohibited people of Motunui to cross the ocean, but Moana still continued her desire although her father banned her. Moana did it because she should save the island and the people of Motunui by returning the heart of Te-Fiti.

\section{CONCLUSION AND SUGGESTION}

The researcher concluded from the movie Moana that a strong desire and brave change from fear to be brave and confident. Someone who has a big desire and any difficulties must face and dare to make it happen. Id, ego and super-ego of Moana in the movie has a big desire to go to the ocean. She can cross the ocean because she wanted to save the people of Motunui Island from economic down turn. Moana has a big desire (id), but the super-ego from her family and the rule of island made ego cannot controlled id and a rule from super-ego. Furthermore, in several scenes the ego in Moana can managed the desire of id and super-ego. Thus, this movie wants to inform that a big desire of person should satisfy even though a big obstacles block out our desire. While that desire is good for self and for other people, it should satisfy.

Based on the conclusion above, the recommended suggestions that the 
researcher could give are movie Moana is needed to be further analyzed. This movie has some messages about the desire of child. Therefore, the researcher suggested to the next researcher to analyzed more deeply because this research only limited to psychological aspects. This research also expected to enrich the knowledge of the reader about psychoanalysis, especially for student of Faculty of Letters who will take similar topic of research.

\section{REFERENCES}

A.S.Mcleod. Retrieved January 15, 2014, from Psychoanalysis: https://www. simplypsychology.org/psychoanalysis.html

Ackerman, C. (n.d.). Retrieved May 7, 2018, from https://positivepsychologyprogram. com/psychoanalysis/\#definition psychoanalysis

Arifin, K. L. (2016). "Personality in Terry McCaleb, The Major Character of Blood Work Movie: A Psychoanalytic Approach." Surakarta: (Unpublished Dissertation) Muhammadiyah University.

Bedewoda, G. A. (2015). "Karakteristik dan Permasalahan Psikologis Tokoh Utama Harry dalam Roman Der Steppenwolf Karya Herman Hesse: Pendekatan Psikoanalisis." Yogyakarta: (Unpublished Dissertation) Faculty of Language and Art Yogyakarta University.

Osnat., S. (Producer), Clements, R., \& Musker, J. (Directors). (2016-2017). Moana [Motion Picture].

Freud, S. (1960). The Ego and the Id. (J. Riviere, Trans.) New York: W.W. Norton \& Company.

Friedman, H. S., \& Schustack, M. (2006). Kepribadian: Teori Klasik dan Riset Modern (3rd ed., Vol. I). (F. D. Ikarini, M. Hany, \& A. P. Prima, Trans.) Jakarta: penerbit Erlangga.

Hall, C. S. (1954). A Primer of Freudian Psychology. New York: The New American Library Limited.

Irwanto, P. (2018). Sejarah Psikologi: Perkembangan Perspektif Teoritis. Jakarta: PT Gramedia Pustaka Utama.

Kuravatti, K. P., \& Malipatil, R. P. (2017). Factors Affecting of Personality Development, 607-609.

Lapsley, D., \& Stey, P. C. (2011). "Id, Ego and Superego." Encyclopedia of Human Behavior, 1-8. 
Putra, E. K. (2016). "The Psychological Problem Experienced by The Main Character in Lauren Weisberger's The Devil Wears Prada." Jember: (Unpublished Dissertation) English Department Faculty of Humanities Jember University.

Rahayu, A. A. (2017). "Psychoanalysis of Lesbians and Gays in The Great Gatsby Novel." Situbondo: (Unpublished Dissertation) University of Abdurachman Saleh Situbondo.

Rokhana, S. (2016). "Analisis Tokoh Utama dengan Teori Psikoanalisa Sigmund Freud pada Cerpen Hana Karya Akutagawa Ryunasuke." Semarang: (Unpublished Dissertation). Faculty of Language and Art University of Semarang.

S.Hall, C. (2019). Psikologi Freud: Sebuah Bacaan Awal. (C. S. KM, Trans.) Yogyakarta: IRCiSoD.

Sobur, A. (2013). Psikologi Umum dalam Lintasan Sejarah. Bandung: CV Pustaka Setia. 